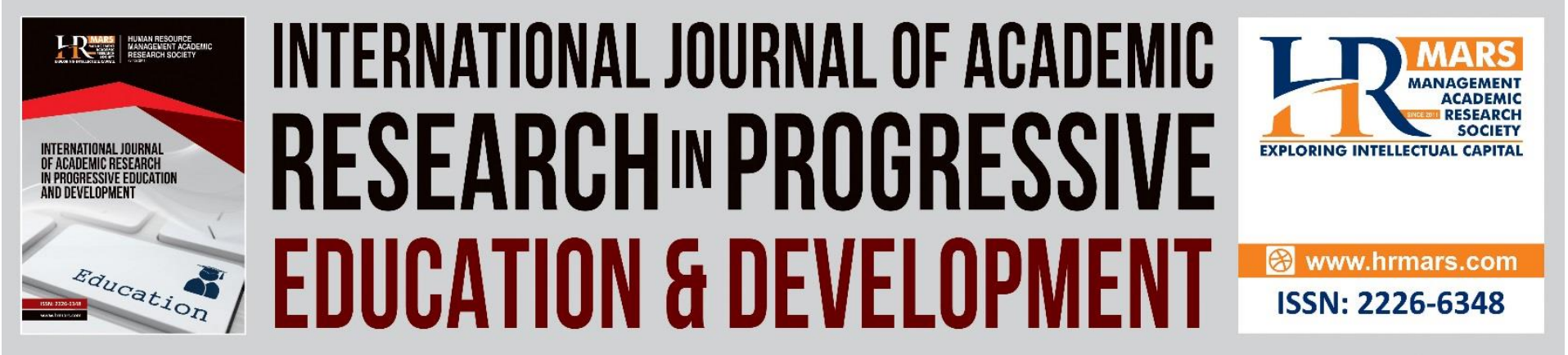

\title{
Ibn Qutayba's Response to the Slanderers who Claim Grammatical Mistake in the Qur'an
}

Mohamed Fathy Mohamed Abdelgelil, Ammar Kamal Ibrahim Othman, Reda Owis Hassan Serour, Mahmoud Fathy Mohamed Abdelgalil Osman, Ahmad Fauzi Hassan

To Link this Article: http://dx.doi.org/10.6007/IJARPED/v10-i3/11003

DOI:10.6007/IJARPED/v10-i3/11003

Received: 01 July 2021, Revised: 06 August 2021, Accepted: 27 August 2021

Published Online: 18 September 2021

In-Text Citation: (Abdelgelil et al., 2021)

To Cite this Article: Abdelgelil, M. F. M., Othman, A. K. I., Serour, R. O. H., Osman, M. F. M. A., \& Hassan, A. F. (2021). Ibn Qutayba's Response to the Slanderers who Claim Grammatical Mistake in the Qur'an. International Journal of Academic Research in Progressive Education and Development, 10(3), 419-426.

Copyright: (C) 2021 The Author(s)

Published by Human Resource Management Academic Research Society (www.hrmars.com)

This article is published under the Creative Commons Attribution (CC BY 4.0) license. Anyone may reproduce, distribute, translate and create derivative works of this article (for both commercial and non-commercial purposes), subject to full attribution to the original publication and authors. The full terms of this license may be seen at: http://creativecommons.org/licences/by/4.0/legalcode

Vol. 10(3) 2021, Pg. $419-426$

http://hrmars.com/index.php/pages/detail/IJARPED

JOURNAL HOMEPAGE

Full Terms \& Conditions of access and use can be found at http://hrmars.com/index.php/pages/detail/publication-ethics 


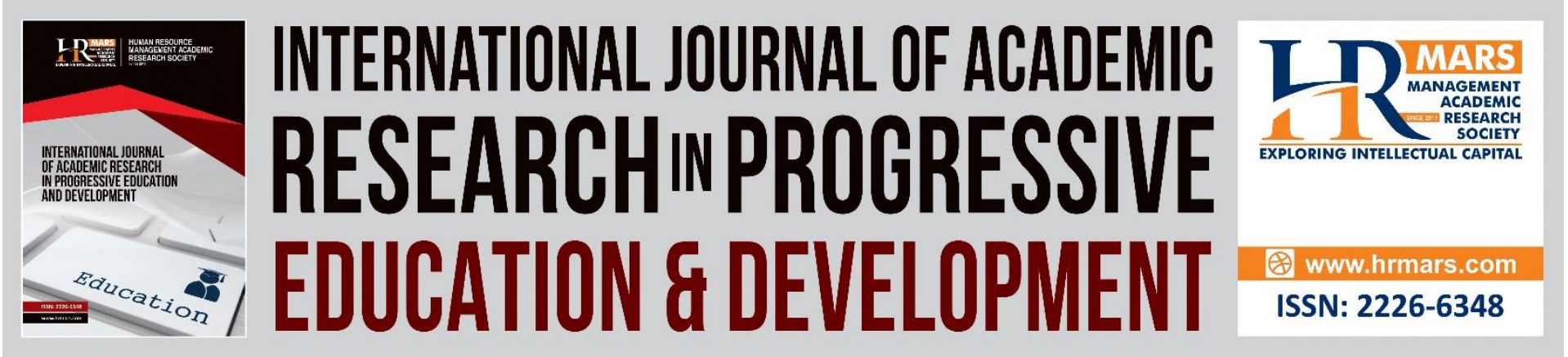

\title{
Ibn Qutayba's Response to the Slanderers who Claim Grammatical Mistake in the Qur'an
}

\author{
${ }^{1}$ Mohamed Fathy Mohamed Abdelgelil, ${ }^{1}$ Ammar Kamal Ibrahim \\ Othman, ${ }^{2}$ Reda Owis Hassan Serour, ${ }^{3}$ Mahmoud Fathy \\ Mohamed Abdelgalil Osman, ${ }^{1}$ Ahmad Fauzi Hassan \\ ${ }^{1}$ Faculty of Islamic Contemporary Studies (FKI), Sultan Zainal Abidin University (UniSZA), \\ 21300, Terengganu, Malaysia, ${ }^{2}$ Sultan Abdul Halim Mu'adzam Shah International Islamic \\ University, (UniSHAMS), Malaysia, ${ }^{3}$ Sharjah Islamic Affairs, The United Arab Emirates (UAE) \\ Email: mfathy@unisza.edu.my
}

\begin{abstract}
Those who slander the Holy Qur'an have methods and paths in order to bring suspicions about the Noble Qur'an and its sciences and to make people question it, and here lies the problem of the research, which aims to show the responses of the scholars, may Allah Almighty have mercy on them, including Imam Ibn Qutayba, the showing of his defense against the allegations made about the alleged grammatical mistakes in the Holy Qur'an. This research is based on the analytical approach, which traces the points where Ibn Qutayba triumphs over slanders and their readings. As a result of this research, the Holy Qur'an did not prove any grammatical mistakes or errors in it. If a mistake occurred from one of the writers of the Qur'an, it is the fault of the writer, and there is no mistakes in the Qur'an. It also became clear that grammar, poetry, and syntax are among the ways of responding to the slanders of the Qur'an according to Ibn Qutaybah, and that his book, "TA'WEL MUSHKAL ALQURAN", is considered an important book in making triumph for the Qur'an and answering the claims of the slanderers
\end{abstract}

Keywords: Slanderers, Ibn Qutayba, Response, the Qur'an, Grammatical Mistakes.

\section{Introduction}

The Holy Qur'an is one of the greatest miracles of Allah that He revealed to His greatest messengers, may Allah bless him and grant him peace. There have been numerous studies regarding it, including interpretation, grammar, written form, vowelization, and others. It is one of the greatest books which numerous writings were written about it, long and short. It is the sea that does not dry up, and the good that does not stop.

\section{Preface}

Since the Noble Qur'an was revealed, the slanderers have been challenging it in order to deter people from the truth in it, out of envy and aggression from them, and the Holy Qur'an is still proud of its authenticity and veracity. The reason for this is that Allah Almighty has ensured 
its protection. Some of those slanderers came under the Qur'an and the readings contained therein, they delt with them from the side that the Qur'an has grammatical mistakes. However, scholars confronted them and responded to their allegations with evidence and proofs. Among these scholars is Imam Ibn Qutayba, may Allah have mercy on him, and some of his efforts will be present in this research.

\section{Ibn Qutayba's Response to the Slanderers who Claim Grammatical Mistake in the Qur'an} Slanderers invoked by what was narrated on the authority of Aisha, may Allah be pleased with her, that she said: Three letters in the book of God are a mistake by the writer": Allah's saying

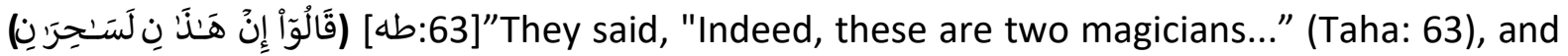
in Surah Alma'eda: Indeed, those who have believed [in Prophet Muhammad] and those

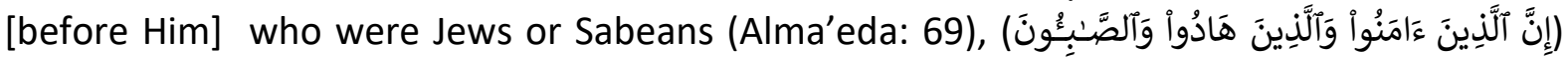
[ائدة:69]and in Surah Annisaa: But those who are firm in knowledge among them and the believers believe in what has been revealed to you, [O Muhammad], and what was revealed before you. And the establishers of prayer [especially] and the givers of zakah (Annisaa: 162)

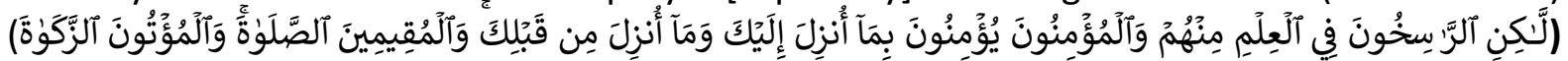
[النساء:162]") (Al-Tabari, 2000, 9/395).

Ibn Qutayba explained that what they said regarding what was reported on the authority of Aisha and Uthman, may Allah be pleased with them both, that these letters are not free from being on one of the school of the people of syntax, or they could be the writer's mistake as mentioned by Aisha, may Allah be pleased with her. If it is following the schools of syntax, then there is no mistake here, praise be to Allah, and if it was a mistake in the book, then his Messenger, may Allah bless him and grant him peace, has no fault in the writer's mistake, And if this was a fault that was attributed to the Qur'an, then every mistake that occurred in writing the Qur'an by spelling would be reverted to it, as the writers of the Qur'an wrote:

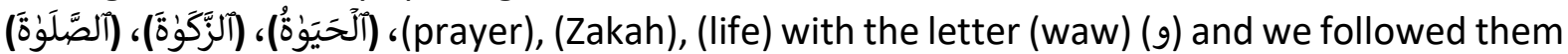
in the way they write these words, although we write: (القطاة، والقناة، والفلاة)، (sand grouse, cannal, and desert) only with the letter (alif) (I), and there is no difference between these

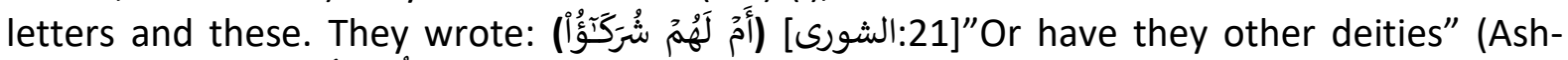

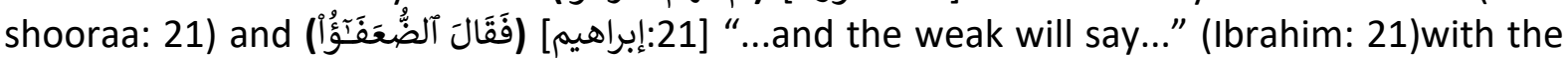

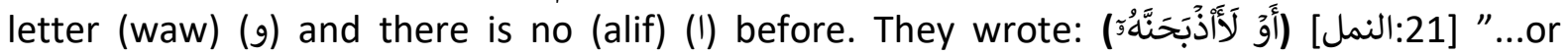
slaughter him..." (an-Naml: 21) with an added (alif) (I) and this is in the Quranic manuscript more than we can investigate (Ibn Qutayba, 2002, 42)

The grammarians spoke about these letters and their like; they found a reason for each of

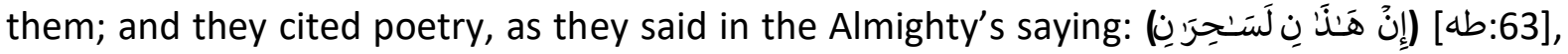
"They said, "Indeed, these are two magicians" (Taha: 63), it is the dialect of Belharith bin Kaab, they say: I passed by two men, took two dirhams from him, and sat in his hands, and they sang:

He took a hit between his two ears ... That he fall of no effect in the dust (Ibn Manzur, 1994, 8/197)

Which means: A very dusty place that does not sprout.

And they recited:

(اروا علاهنّ فطر علاها ...أيّ قلوص راكب تراها (Ibn Manzur, 1994, 15/89)

Then he indicated that the readers differed in the reading of this letter: So Abu Amr bin AlAlaa, and Isa bin Omar recited : "إنّ هذين لساحران", “...these are two magicians..." (putting the demonstrative noun in accusative case), they concluded that it was a mistake by the writer, 


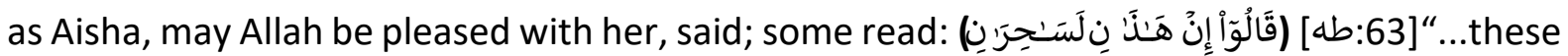
are two magicians..." (Taha: 63) based on the reading of Obai, may Allah be pleased with him; because it is in his Qur'anic manuscript: "إن ذان إلّا ساحران", and in Abdullah's Qur'anic manuscript, may Allah be pleased with him: "وأسرّوا النّجوى أن هذان ساحران "and concealed their private conversation, They said, "Indeed, these are two magicians" in the accusative case with

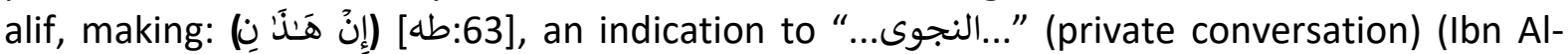
Jazari, 2000, 459; Al-Nawwazi, 2018, 3/1232)

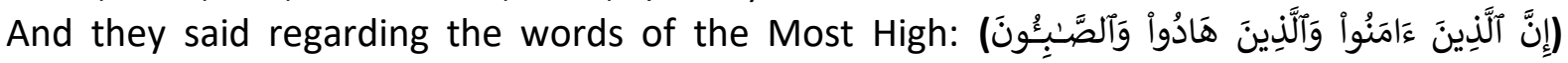
[الصّابئين) is in the nominative case, because because it is a response to:

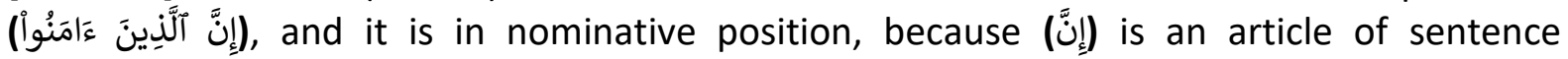
commencement, and does not add any meaning to speech unlike similar articles, as it is said: زيد قائم (Zaid is standing), زيد زيداً قائم : زيد (Zaid in nominative case, then you say is standing), زازيداً

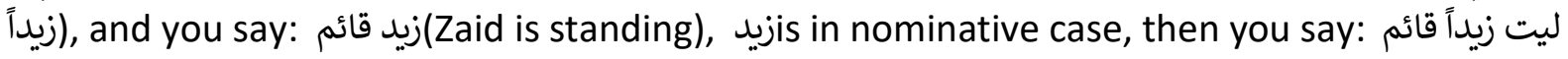

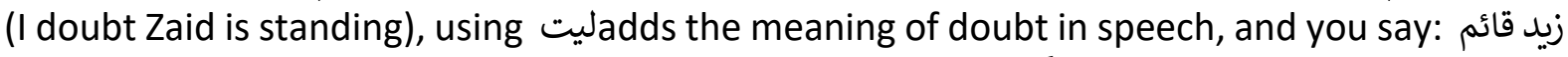
(Zaid is standing), زيدis in nominative case, then you say: ليد زيداً قائم (I wish Zaid is standing), using ليت إنّ عبد : الله قائم وزيد (Abdullah is standing and Zaid), Zaid in in nominative case as if you said: عبد الله

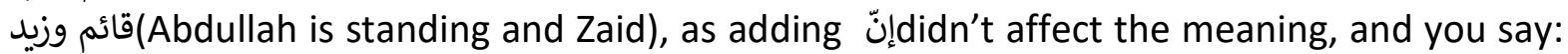
لعلّ عبد الله قائم وزيداً (Perhaps Abdullah is standing and Zayd). Zaid is in accusative case when using (لعلّ) (perhaps) and is in nominative case when using (لعلّ) (إن) (perhaps) brought about the meaning of doubt in speech, and because (إن) did not add any meaning to the speech. (Ibn Qutayba, 2002, 37)

And they said about the reason why the word (النساء) [والْمُقِيمِينَ):162], “...And the establishers of prayer..." (an-Nisa': 162) is in the accusative case some sayings: He means what had been revealed to you and to the establishers of prayer, and some said: What was revealed before

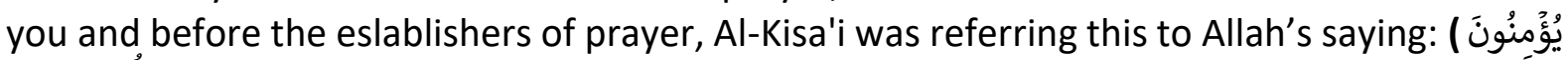

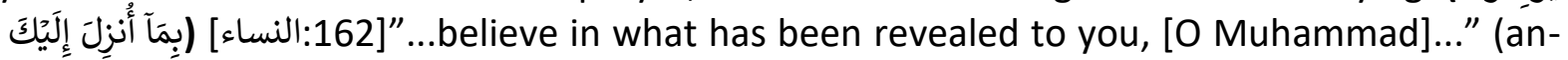
Nisa': 162) i.e: And they believe in the establishers, and he considered his saying in another

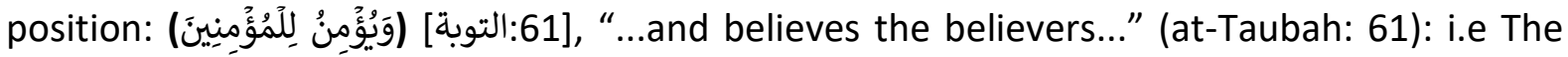
believers, and some said: It's an accusative case because of praise, Abu Obaida said: It's an accusative case because of the speech length by order, and he recited what Kharang Bint Havan said:

I wish safety from perdition for my people

Those who are like poison to their enemies, and who greatly honor their guests

who participate in all battles and

who are the symbol of chastity

Ibn Qutayba came with other points in the Qur'an that are similar to the points previously mentioned, and the slanderers did not mention them, then he explained the form of each point, and its reason (Ibn Qutayba, 2002, 39).

\section{Refutation of those who Object to the Revelation of the Similarities in the Qur'an}

Slanderers were confused by saying: Why did Allah revealed similarities in the Qur'an, he who wanted the Qur'an for his servants to guide and clarify? 
Then Ibn Qutayba replied that the Qur'an was revealed in Arabic words, their meanings, and their doctrines in brevity and abbreviation, lengthening and emphasizing, and referring to something; making some of the meanings vague that no one but the smart knows them; and exposing some of them; setting proverbs for what is hidden; and if the entire Qur'an was clear that the knowledgeable and the ignorant were equal in knowledge, the differentiation between people would be invalidated, and the trial would have ended, and thoughts would have died. With need comes idea and trick, and with satisfaction comes helplessness and dullness, and they said: The defect of wealth is that it begets idiocy, and the virtue of poverty is that it rise trickery Aktham bin Saifi said: "If the whole world was to be in my hand, that wouldn't please me, he was asked: why? He said: "I hate the habit of helplessness"(Ibn Qutayba, 1998, 1/353).

Each chapter of knowledge: Of jurisprudence, arithmetica, ordinances and grammar, some of it is can be apparent, and some of it can be hard to reach, so that the scholar rises rank after rank until he reaches its limit, and attain its highest point. In addition to the scholar's attaining the virtue of contemplation, and good extraction. Let the reward of Allah be for those who benevolently care.

And if every art of science were one thing, there would not be a scholar or a learner, or a hidden or an obvious. Because the virtues of things are known by their opposites, so the good is defined by the bad, and the benefit by harm, the sweet by the bitter, the little by the greater, the small by the big, and the inward by the outward.

According to this example, the words of the Messenger of Allah, peace and blessings of Allah be upon him, and the words of his companions and followers, the poems of poets, and the words of the orators, nothing of which may come in, but the gentle meaning in which the advanced schooler progresses, and the skillful researcher acknowledges the failure to it (Ibn Qutayba, 2002, 58).

Then Ibn Qutayba mentioned many examples from the words of the Prophet, may Allah bless him and grant him peace, and his honorable companions, as well as the words of the Arabs, their proverbs, and their poems, and he clarified some of them. Then he made it clear that had it not been for the scholars who explored the meanings of such sayings, their meaning would not have become clear to us, nor would their implication be clear to us, and what they meant by them.

And he made it clear that he is not one of those who claims that the similarities in the Qur'an are not known by those those who are sound in knowledge, because this is a mistake from the interpreter of it in language and meaning, Allah Almighty did not reveal anything from the Qur'an except for the benefit of His servants, and to indicate a meaning he wanted, as if similarities were unknown except for him, the slanderer would have been right in his saying, and his reason were to be accurate.

Can someone say: that the Messenger of Allah, may Allah bless him and grant him peace, did not know similarities?!

And if it was permissible for him to know ot according to Allah's saying: (And no one knows its [true] interpretation except Allah) (Al-Imran: 7)then it is permissible for the pious of his companions to know it, for he taught Ali, may Allah be pleased with him, the interpretation, and he made supplication for Ibn Abbas, may God be pleased with them both saying: "O Allah! Teach him (Ibn 'Abbas) interpretation and make him a learned scholar in religion (Islam)." (AlTabarani, 2005; 10/238; Al-Bukhari, 2002, 41/1)And on the authority of Mujahid, he said: You know it and you say: We believe in it (Al-Tabari, 2000, 6/203). 
And if those who are sound in knowledge had no luck in similarities, except to say: (We believe in it. All [of it] is from our Lord.) (Al-Imran: 7)the sound in knowledge wouldn't have preference over the educated, but over the ignorant Muslims; because they all say: (We believe in it. All [of it] is from our Lord), and we did not see the interpreter stopped interpreting anything of the Qur'an and said: "This is similar only Allah knows". Rather, they imposed it all upon interpretation, to the extent that they explained (separate letters) in the beginning of the surahs, such as: (Alif, Lam, Ra), ( $\mathrm{Ha}, \mathrm{Meem})$ and $(\mathrm{Ta}, \mathrm{Ha})$ and the like.

If someone said: How is it permissible in language for those who are sound in knowledge to know it, and Allah Almighty says: (And no one knows its [true] interpretation except Allah)) (Al-Imran: 7)And if you associate those who are sound in knowledge, they will be in separation from the verb (say) and there is no nasaq waw (a connective particle) that obliges those who are soun in knowledge making two acts. This is the doctrine of many grammarians in this verse, and some of the interpreters have made mistakes regarding it?

We told him: That (say) here is in the sense of an adverb, as if he said: Those who are sound in knowledge saying: We believe in it, this is similar in speech to: None but Abdullah comes to you, and Zaid says: I am happy with your visit, he means: None but Abdullah comes to you, and Zaid saying: I am happy with your visit.

And the same for Ibn Mufrig al-Himyarilaments a man in a poem that starts with:

Did cut your rope from the front Days after it was tied up

And the wind cries out of sadness, and the lightning shines in a cloud (Ibn Mufrig, 1982, 208). He means: And the lightning is shining in a cloud that weeps as well, and if the lightning did not associate the wind in crying, the mention of the lightning and its shining would have no meaning. (Ibn Qutayba, 2002, 67).

Ibn Qutayba refuted the problems with which the slanderers defame the readings and the writing of the Quranic manuscript, and explained the wisdom of Allah Almighty's revelation of the Qur'anic similarities, so Allah revealed the truth through it, and explained the argument that refuted the slanderers' slander, and the lies of the slanderers. This is from Allah's Almighty preservation of his book in harnessing the people of knowledge to defend it, and to advocate for it with argument and proof.

Although Ibn Qutayba benefited from Abu Ubaidah and al-Far' in many meanings, they did not discuss what was ambiguous about the Qur'an from what was not from the meanings, as Ibn Qutayba did.

Al-Far' and Al-Akhfash had some indications to the illusive that believes in the difference and contradiction between the meanings in the Qur'anic verses - as previously explained - except that Abu Ubaidah, Qutrub, Al-Akhfash, and Al-Farra, as well as the rest of the commentators, had no words in their view on refuting the claims of the slanderers in what is outside the scope of meanings, as Ibn Qutayba did in singling out this blessed work, "TA'WEL MUSHKAL ALQURAN"; In spite of its small size, you find in it a lot of repelling the claims of slanderers regarding the readings, the written form the Qur'an, and similarities, and removing ambiguity in meanings, syntax, and Arabic linguistic styles, and the most prominent of which is the Qur'anic rhetoric. Indeed, it is the first book written on the Qur'anic rhetoric, with simplifying it; making it easier to comprehend, and the removing of ambiguity that have arisen to it.

Despite the great benefit of this book, however, Abu Ubaidah and Al-Farra played a major role in influencing its content, especially Al-Farra, which had the most important role in Ibn Qutayba's benefit from him in solving many problems and clarifying many meanings. 


\section{Conclusion}

After we went through this interesting Quranic research, which serves an important part about the Quran and its triumph, we reached several results, the most important of which are:

1. There is no grammatical mistake or error in the Qur'an, big or small, little or great.

2. It may happen a little throughout Islamic history that a writer misses a letter or two, but this does not mean that mistakes are in the Qur'an, but rather the mistakes are of the writer.

3. Grammar, syntax, and poetry are among the ways that Ibn Qutayba relied on in responding to the slanderers in the Holy Qur'an.

4. The book, "TA'WEL MUSHKAL ALQURAN" by Ibn Qutayba, despite its small size, is considered one of the books that served the Holy Qur'an in its triumph against the claims of the slanderers.

\section{References}

Al-Quran Al-Karim.

Abdelgelil, M. F. M. (2020). Grammarians' Critique of Qur'anic Qira'at. International Journal of Academic Research in Business and Social Sciences, 10(11), 1225-1231.

Abdelgelil, M. F. M. (2020). Solving the Quranic Issues with Quranic Qira'at, International Journal of Academic Research in Business and Social Sciences, 10(12), 36-42.

Abdelgelil, M. F. M., Al-Janayni, M. U., Baru, R., Hamzah, M. S., Razali, M. A. T. M., \& Ismail, F. Z. (2018). Tawjih Al-Qira'at Based on Inscription, Language, and Unusual Modes of Recitation According to Ibn Zanjalah. International Journal of Academic Research in Business and Social Sciences, 8(10), 362-370.

Abdelgelil, M. F. M., Daud, N. B., Omar, N. B., Ismail, F. Z. B., \& Wahab, A. H. B. A. (2018). Taujeeh Al-Qira'at Using Qur'an, Hadith and Poetry according to Ibn Zanjalah. International Journal of Academic Research in Business and Social Sciences, 8(10), 371-379.

Abdelgelil, M. F. M., Hasan, A. F., Yusoh, F, El khayat, M. H. M., Razali, M. A., Ismail, F. Z., \& Ab Rashid, R. (2021). Correlation Between Irregular Qiraat And Arabic Linguistics In The Quranic Tafseer Book By Al-Razi. International Journal of Academic Research in Business and Social Sciences, 11(7), 1632-1639.

Abdelgelil, M. F. M., Hasan, A. F., Yusoh, F., Ismail, F. Z., Ab Rashid, R., Ab Aziz, N. S., Hassan, A (2021). The Impact of Irregular Qiraat on Arabic Semantics and Dialects. International Journal of Academic Research in Business and Social Sciences, 11(7), 1672-1676.

Abdelgelil, M. F. M., Hasan. A. F., Yusoh, F., El khayat, M. H. M., Razali, M. A., Hassan, A., Ab Aziz, N. S. (2021). Arabic Syntactic Rules with Reference to Quranic Qurra. International Journal of Academic Research in Business and Social Sciences, 11(7), 1707-1711.

Abdelgelil, M. F. M., Musolin, M. H., Serour, R. O. H., Abdullah, M. S., \& Noor, M. N. M. (2018). Law and Moral Values in the Holy Quran. International Journal of Academic Research in Business and Social Sciences, 8(11), 445-451.

Albukhari, M. B. I. (2002), Sahih Albukhari. Tahqiq: Muhammad Zuhair Bin Nasir Alnasir. Alqahirah: Dar Tawq Alnajah. 
Alnauzawazi, M. A. (2018). Almughni Fi Alqira'at. Tahqiq: Mahmud Bin Kabir Bin 'Eisa Alshinqiti. Alriyad: Aljami'ah Al'Eilmiyah Alsu'udiyah Lilqur'an Alkarim Wa'Ulumih.

Altabarani, S. B. A. (2005). Almu'jam Alkabir. Tahqiq: Hamdi Bin 'Abd Almajid Alsalafi. Alqahirah: Maktabah Ibn Taimiyah.

Altabari, M. B. J. (2000). Jami'e Albayan Fi Ta'wil Alquran. Tahqiq: 'Ahmad Muhammad Shakir, Beirut: Mu'asasat Alrisalah.

Ibn Aljazari, M. B. M. (2000). Tahbir Altaysir Fi Alqira'at Al'Ashr. Tahqiq: 'Ahmad Muhammad Muflih Alqudah. 'Amman: Dar Alfurqan.

Ibn Manzur, M. B. M. (1994). Lisan Al’Aarb. Beirut: Dar Sadir.

Ibn Mufarrigh, Y. A. (1982). Diwan Yazid Bin Mufarrigh Alhimiari. Jam' Watahqiq: 'Abd Alquddus 'Abu Salih, Mu'asasat Alrisalah, Beirut: Altab'ah Althaniyah.

Ibn Qutaybah, A. B. M. (1998). 'Uyun Al'Akhbar. Beirut: Dar Alkutub Al’Eilmiyah.

Ibn Qutaybah, A. B. M. (2002). Ta'wil Mushkil Alquran. Tahqiq: Ibrahim Shamsuddin, Beirut: Dar Alkutub Al'Elmiyah. 